\title{
Transfection of mesenchymal stem cells at physiological oxygen concentrations
}

\author{
N. S. Shuvalova ${ }^{1}$, E. K. Toporova ${ }^{1,2}$, V. A. Kordium ${ }^{1,2}$ \\ ${ }^{1}$ Institute of Genetic and Regenerative Medicine, NAMS of Ukraine \\ 67, Vyshgorodska Str., Kyiv, Ukraine, 04114 \\ ${ }^{2}$ Institute of Molecular Biology and Genetics, NAS of Ukraine \\ 150, Akademika Zabolotnoho Str., Kyiv, Ukraine, 03143 \\ shuvalovanadiia@gmail.com
}

\begin{abstract}
Aim. Numerous works showed the beneficial effect of oxygen in physiological concentrations on mesenchymal stem cells (MSC) cultures. The aim of the present work was to study the impact of physiological oxygen tensions on non-viral transfection of MSC from human Wharton jelly (WJ-MSC). Methods. WJ-MSC at passage 2 were cultivated for 48 hours in different gas mixtures: nitrogen-based (oxygen $-3 \%, \mathrm{CO}_{2}-5 \%$, nitrogen $-92 \%$ ) and argon-based (oxygen $-3 \%, \mathrm{CO}_{2}-5 \%$, argon $-92 \%$ ), while the control group was cultivated under standard conditions of $\mathrm{CO}_{2}$-incubator (ambient oxygen concentration, $\mathrm{CO}_{2}-5 \%$ ). After 48 hours of cultivation the cells were transfected with polyplexes pEGFP-C1/PEI/ and pEGFP$\mathrm{C} 1 /$ TurboFect, containing $3 \mu \mathrm{g}$ of plasmid DNA. The cultures were in contact with complexes for 1 hour, at standard conditions of $\mathrm{CO}_{2}$-incubator. Next, the media were changed, and WJ-MSC were cultivated for 48 hours in described gas mixtures, and $\mathrm{CO}_{2}$ - incubator. Transfection effectiveness was estimated by flow cytometry as the number of eGFP+ fluorescent cells, (BD FACSAria). Results. In the groups cultivated in gas mixtures containing $3 \%$ of oxygen, the number of cells, synthesizing eGFP+ before and after the transfection procedure, was on average 2.58 times higher in the nitrogen-based mixture and 1.37 times higher in the argon-based mixture than in control groups from the $\mathrm{CO}_{2}$-incubator. Conclusions. The cultivation of human WJ-MSC under physiological oxygen tensions allowed an increase in the percentage of transfected cells, and is promising to be used as a method for optimization of transfection.
\end{abstract}

Ke y w or d s: mesenchymal stem cells, non-viral transfection, Wharton jelly, hypoxia, argon

\section{Introduction}

Mesenchymal stem cells (MSC), a population of adult stem cells, are considered to be per- spective tool for regenerative medicine [1]. At present, their therapeutic potential is attributed

(C) 2020 N. S. Shuvalova et al.; Published by the Institute of Molecular Biology and Genetics, NAS of Ukraine on behalf of Biopolymers and Cell. This is an Open Access article distributed under the terms of the Creative Commons Attribution License (http://creativecommons.org/licenses/by/4.0/), which permits unrestricted reuse, distribution, and reproduction in any medium, provided the original work is properly cited 
to their unique immunomodulatory and paracrine activity. The ability to produce a wide range of bioactive molecules is viewed as the underlying mechanism of their therapeutical effects.

Considering, that the original number of MSC in different tissues is comparatively low [2], their ex-vivo multiplication is required for obtaining the cells in amount, sufficient for scientific research and clinical application [3]. Since the widely acknowledged conditions of cultivation differ from those of MSCs natural location sites, the process of in vitro cultivation is often accompanied by the cell damage, degradation of culture and, as the result, loss of the therapeutic potential [4-6]. Thus, one of the major tasks of regenerative medicine is the development of cultivation protocols for MSC (and other populations of stem cells) to provide the maximal preservation of their original therapeutically significant properties [4].

At present, one of the novel methods, that allows an increase in the amount of therapeutically significant molecules and paracrine factors, and enhancement of the therapeutic potential of MSC from various sources, is the transfection of MSC with target genes, using various viral and non-viral constructions [7-9]. The important emerging biotechnological task is to optimize the existing systems for the delivery of genetic material into cells, and to develop the new ones. Main disadvantages of the existing viral transfection methods include toxicity, immunogenicity, and potential genetic instability in cells, leading to oncogenesis. All of above drawbacks restrict the possibility of practical application of these methods [10].
Non-viral vectors, comparing to viral vectors, are considered to be safer, non-infectious, non-immunogenic, and less toxic. They can be obtained by simple methods in large amounts and have the ability to transfer the genes with large size [11]. Non-viral methods are thought to be optimal for the cases, when the constitutive transgene expression is not necessary. But their major disadvantage is a low transduction efficiency [12]. Therefore, the development of methods, that allow the improvement in the non-viral transfection efficiency and the enhancement of the following expression of target product is considered to be a perspective trend in biotechnology. One of the most important tasks is the optimization of above methods for transfection of MSC.

It was shown, that one of the MSC distinguishing features is their localization in the sites of organism with low oxygen concentration, irrespectively of their tissue origin [13]. At present, the MSC cultivation at physiological oxygen concentrations (approximately $1.5-8 \%$ ) is considered to be the promising method, that allows preventing pre-time senescence [14], enhancement of migratory potential and increasing the number of survived cells after transplantation to ischemic sites $[15,16]$. Additionally, the enhancement of MSC paracrine activity in conditions of mild hypoxia is detected [17]. The studies showed the effectiveness of various strategies of using lower oxygen concentrations: from long-term cultivation $[14,18]$ to short-term preconditioning $[19,20]$. Considering the present literature, we hypothesized that conducting the transfection in conditions of mild hypoxia would have beneficial effects on the cell survival and the expression of target product. 
The aim of the present work was to study the impact of low oxygen concentrations on the effectiveness of transfection and to determine whether the cultivation in mild hypoxia conditions can be used as a method for optimization of non-viral polyplex-gene delivery to stem cells in vitro.

\section{Materials and Methods}

Obtaining the primary MSC cultures from Wharton jelly. MSC were isolated from human Wharton jelly (WJ) by the explant method, as described in our previous works [21,22]. Umbilical cords (UC) were obtained from three healthy donors (39-40 weeks of gestation, normal delivery), after informed consent. The UC fragment $(5-10 \mathrm{~cm})$ was washed twice with PBS, the blood vessels were mechanically removed. WJ was minced, and the fragments were placed in the cultural flacks, $75 \mathrm{~cm}^{2}$, with complete expansion medium: aMEM(BioWest, supplemented with $10 \%$ fetal bovine serum (HyClone), penicillin $100 \mathrm{U} / \mathrm{ml}$ (Arterium, Ukraine), streptomycin $100 \mu \mathrm{g} / \mathrm{ml}$ (Arterium, Ukraine). The attached cells were observed on the 5-7th day. After approx. 14 days, the clones reached the sufficient number $(>10)$ and size, and $70-80 \%$ confluence. After that, the cells were passed with the trypsin-EDTA $(0.1 \%$ trypsin and $0.02 \%$ EDTA) solution.

At passage 1 the cells were studied for the expression of surface marker proteins CD90, CD73, CD105 (over $90 \%$ positive), CD 34 and CD45 (negative) using flow cytometry (BD FACS Aria) with fluorescein - and rhodamine-conjugated antibodies (UsBiological, USA), as descirbed in our previous works [23, 24] . Moreover, the cell cultures were checked for their differentiation ability, as described in our previous works [25].

Gas mixture preparation. For the present study, a system for preparation of nitrogen and argon-based gas mixtures was developed, and described in our previous works [26]. The system consists of 3 gas cylinders with carbon dioxide, nitrogen and argon, air pump, the gas mixing device and the terminal container. The terminal container is connected to the gas analyzer PGA 200 (JSC "Electronstandartpribor", Russian Federation). The gas mixture of required concentration was prepared by regulating the gases outflow from cylinders with air pump and monitoring the indications of gas analyzer.

The flacks and Petri dishes with WJ-MSC cultures were placed into the polyethylene bags with hermetic clasp (1.5 1). Additionally, the Petri dishes with sterile water were placed, to maintain the humidity in the bags. The bags were washed twice with the gas mixture, containing $5 \%$ of $\mathrm{CO}_{2}$ and $95 \%$ of nitrogen or argon (depending on the group), after that they were filled with the prepared gas mixture and placed in the vacuum containers (Scarlet). The containers with bags were kept at $37^{\circ} \mathrm{C}$.

All liquids (cultivation media and PBS), used in the transfection procedure, were preconditioned in required gas mixture, in Petri dishes, for 2 hours. According to the literature, the "liquid media/gas" ratio must be 1:100 [27], to provide normal gas exchange, and the gas concentration in liquid phase becomes the same as in gas phase after maintenance for 1 hour.

MSC cultivation in gas mixtures. Starting from the passage 0 , WJ-MSC were plated on the flacks of $25 \mathrm{~cm} 2,75 \cdot 103$ cells per flack, 
and cultured for 1 subsequent passage. For the transfection procedure, MSC were plated on plastic Petri dishes $(35 \mathrm{~mm})$ at passage 2 . The experimental groups of cultures were maintained in the gas mixtures based on nitrogen (oxygen $-3 \%, \mathrm{CO}_{2}-5 \%$, nitrogen $-92 \%$ ) and argon (oxygen $-3 \%, \mathrm{CO}_{2}-5 \%$, argon $92 \%$ ) since passage 1 . The control group was maintained under the $\mathrm{CO}_{2}$-incubator conditions (ambient concentration of oxygen $-20 \%$, $\mathrm{CO}_{2}-5 \%$ ).

The MSC cultures were observed with an inverted microscope Leica DMIL. Images were taken by camera Cannon PowerShot 640A, $\mathrm{x} 100$, zoom x1.4.

Transfection procedure. The plasmid constructions were prepared, as described by Kordyum et al. [28]. For transfection, nanosized polyplexes $(0.4 \mathrm{~nm})$, which contain plasmid vector pEGFP-C1 (Clonetech), coding the marker gene (enhanced green fluorescent protein - EGFP) and cationic polymers (branched polyethylenimine (PEI, $25 \mathrm{kDa})(«$ Sigma Aldrich») or TurboFect Transfection Reagent (Thermo Fisher Scientific), were used. Polylexes DNA/PEI were prepared ex tempore in weight ratio 1:2. Polyplexes, containing TurboFect, were prepared according to manufacturer's instructions, as described in our previous works [29].

MSC cultures were plated on plastic Petri dishes, $\mathrm{d}=35 \mathrm{~mm}$ (TPP, Switzerland), 9x104 per dish, and cultivated for 48 hours in different gas mixtures: based on nitrogen (oxygen $3 \%, \mathrm{CO}_{2-} 5 \%$, nitrogen $\left.-93 \%\right)(=101 \%$ ?) and argon (oxygen $-3 \%, \mathrm{CO}_{2}-5 \%$, argon $93 \%)(=101 \%$ ?). The control group was cultivated under standard $\mathrm{CO}_{2}$-incubator con- ditions (ambient oxygen concentration $-20 \%$, $\mathrm{CO}_{2}-5 \%$ ).

After 48 hours of cultivation the cells were transfected with polyplexes pEGFP-C1/PEI/ and pEGFP-C1/TurboFect, containing $3 \mu \mathrm{g}$ of plasmid DNA and $6 \mu \mathrm{g}$ of PEI. Cultures were in contact with complexes for 1 hour, in standard $\mathrm{CO}_{2}-$ incubator conditions [29]. After that, the transfection mixture was removed. The cells were washed with PBS twice, and the complete growth media was added.

Next, the cells were cultivated for 48 hours. Depending on the group, MSC were cultivated in the gas mixtures nitrogen-based (oxygen $3 \%, \mathrm{CO}_{2}-5 \%$, nitrogen $-92 \%$ ) and argonbased (oxygen $-3 \%, \mathrm{CO}_{2}-5 \%$, argon $92 \%)$. The control group was maintained under the $\mathrm{CO}_{2}$ - incubator conditions (ambient oxygen concentration $-20 \%, \mathrm{CO}_{2} 5 \%$ ).

Fluorescence of transgenic eGFP in transfected cells was observed with an inverted microscope Leica DMIL, at excitation range $470 / 40 \mathrm{~nm}$ and emission wavelength $\sim 530 \mathrm{~nm}$ (suppression filter $520 / 530 \mathrm{~nm}$ ).

After that, transfection effectiveness was estimated as the number of eGFP-positive cells (cells expressing fluorescence) by flow cytometry (BD FACSAria), using the FACS Diva software.

Statistics. Seven independent experiments were performed. Statistical significance of the difference was determined using MannWhitney U-test at $\mathrm{P}<0.05$.

\section{Results and Discussion}

The major task of the work was to study the impact of conditions of mild hypoxia on the transfection efficiency of human MSC of Wharton jelly. The WJ-MSC cultures were 
used at passage 2 , because our previous works showed that at this passage WJ-MSC preserve high level of proliferative activity, can be obtained in sufficient amounts [21], and have the most homogeneous morphology, without the presence of senescent cells [28].

The characterization of obtained cultures at passage 1 showed, that they fit the generally accepted MSC criteria, being over $95 \%$ positive by CD90, CD73 and CD105, and $>0.3 \%$ negative for CD34 and 45 (Fig 1.)

MSC cultures, maintained in two types of gas mixtures, containing $3 \%$ oxygen (nitrogen-based and argon-based ones), and in standard $\mathrm{CO}_{2}-$ incubator conditions (ambient oxygen concentration), were transfected with pEGFP-C1 DNA plasmid. Five experiments were conducted using PEI, and two - with TurboFect. The fluorescence of transgenic eGFP in transfected cells became detectable after $24-\mathrm{h}$ post-transfection. However, the most intensive fluorescence could be observed after 48 hours (Fig 2). Thus, the general fluorescence intensity, and the percentage of transfected cells were measured by flow cytometry (BD FACSAria) 48 hours after transfection. We also examined the morphology of cultures, and estimated the" live to dead" cells ratio.

Observation by light microscopy did not show any visual difference in morphology between the cells in control and experimental groups. In general, the cells preserved normal spindle-shaped morphology, despite the slight "darkening" of cytoplasm and appearance of small vacuoles in some cells, that can be viewed as a mark of probably slight toxicity of transfection mixture (Fig. 2).

Noteworthy, the transfection yield varied among the donors. For example, Fig. 4. shows the data on transfection yield in experiments (Fig. 4 a,b).

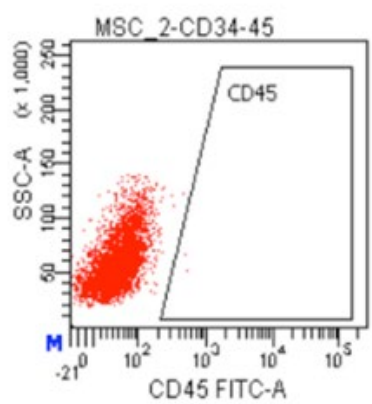

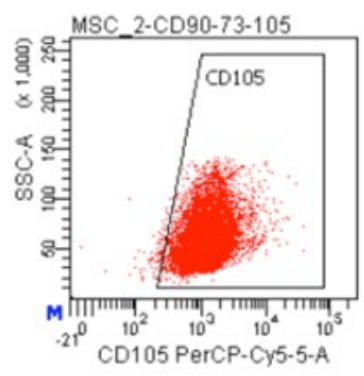
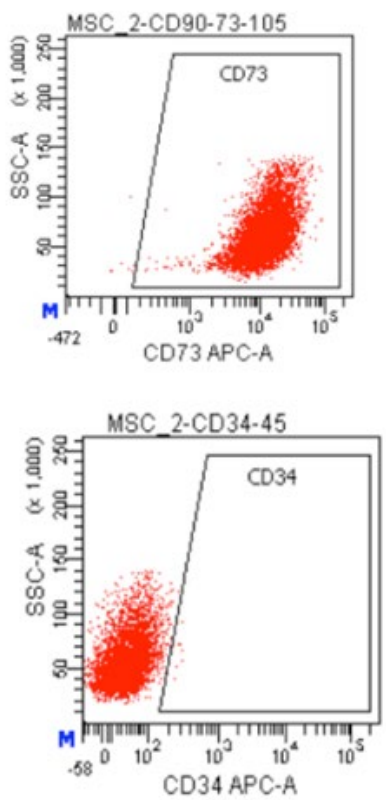

Fig 1. Surface marker protein expression, analysis by flow cytometry (BD FACS Aria). 


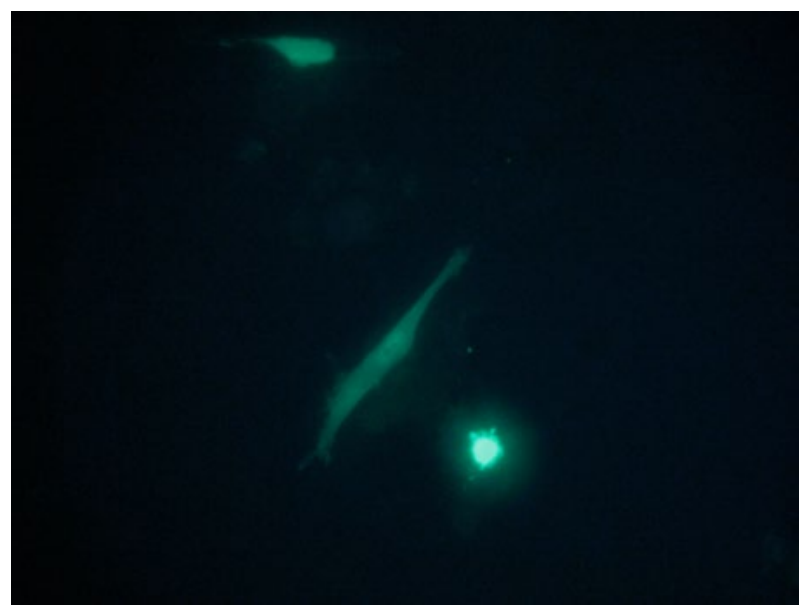

Fig. 2. Fluorescent cell in WJ-MSC culture, 48 hours after transfection. x100, camera zoom x1.4.

Flow cytometry assay (BD-FACS Aria). " $\mathrm{CO}_{2}$-incubator" $-\mathrm{CO}_{2}$ incubator conditions (ambient oxygen concentration $-20 \%, \mathrm{CO}_{2}$ $5 \%$ ), nitrogen-based gas mixture (oxygen $3 \%, \mathrm{CO}_{2}-5 \%$, nitrogen $-92 \%$ ) and argonbased (oxygen $-3 \%, \mathrm{CO}_{2}-5 \%$, argon $92 \%$ ).

However, the task of present pilot work was to compare the effects of mild hypoxia conditions. Because of the detected difference between the variants, to evaluate the results regarding the effect of low oxygen concentrations, we estimated and compared the ratio between the percentage of eGFP + cells in experimental groups (from nitrogen-based and argon-based gas mixtures), to the groups from standard $\mathrm{CO}_{2}$-incubator conditions (Table 1).

Table 1. Efficiency of MSC transfection. The numbers show experimental/control ratio between the number of eGFP+ cells in experimental groups (from nitrogen-based and argon-based gas mixtures), to the groups from standard $\mathrm{CO}_{2}-$ incubator conditions.

\begin{tabular}{c|c|c}
\hline $\begin{array}{c}\mathrm{CO}_{2} \text {-incubator } \\
\text { conditions }\end{array}$ & $\begin{array}{c}\text { Nitrogen-based gas } \\
\text { mixture }\end{array}$ & $\begin{array}{c}\text { Argon-based gas } \\
\text { mixture }\end{array}$ \\
\hline 1 & 8.83 & 2.16 \\
\hline 1 & 1.26 & 0.74 \\
\hline 1 & 1.01 & 1.05 \\
\hline 1 & 2.26 & 1.64 \\
\hline 1 & 1.98 & 1.8 \\
\hline 1 & 1.21 & 0.83 \\
\hline 1 & 1.51 & 1.35 \\
\hline
\end{tabular}

In all experiments, the number of eGFP+ cells was greater in the groups maintained in conditions of mild hypoxia. The most prominent positive effect was detected in nitrogen-
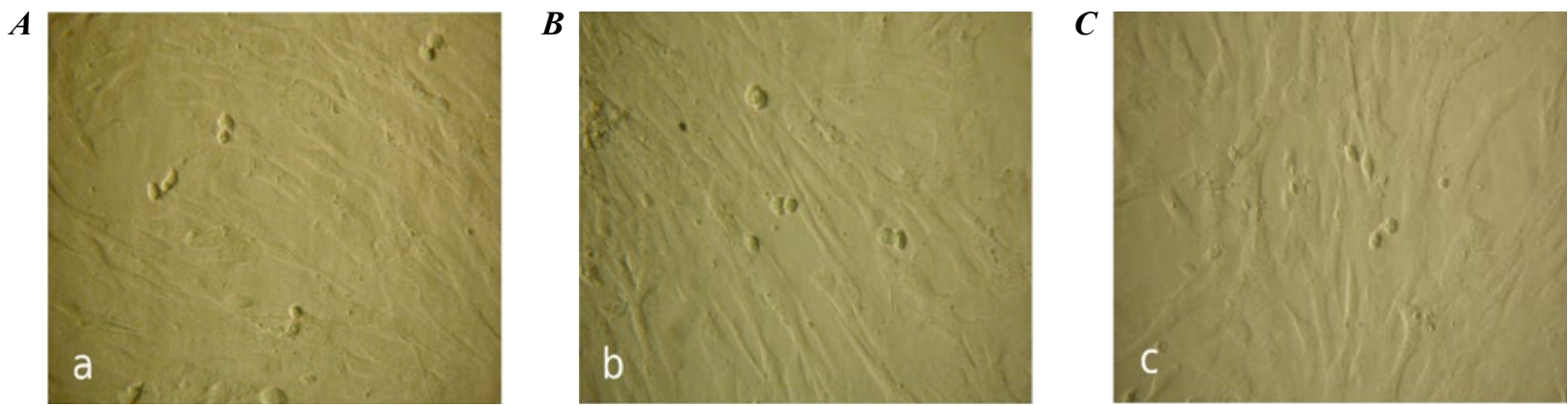

Fig. 3. WJ-MSC cultures, 48 hours post transfection. a - $\mathrm{CO}_{2}-$ incubator conditions, $\mathrm{b}-$ nitrogen-based gas mixture (oxygen $-3 \%, \mathrm{CO}_{2}-5 \%$, nitrogen $-92 \%$ ), c - argon-based gas mixture (oxygen $-3 \%, \mathrm{CO}_{2}-5 \%$, argon $-92 \%$ ), camera zoom x 1.4 . 
Transfection of mesenchymal stem cells at physiological oxygen concentrations

A
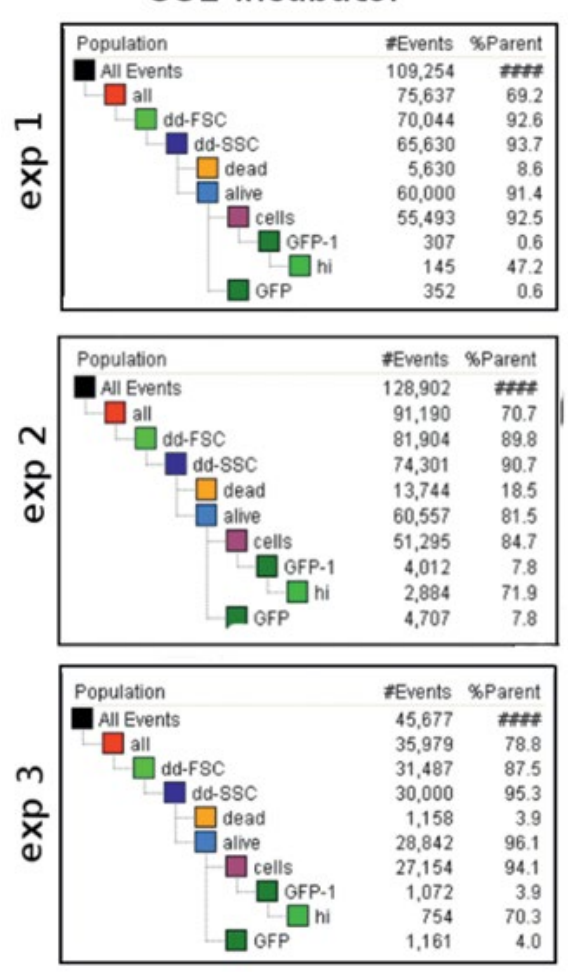

nitrogen

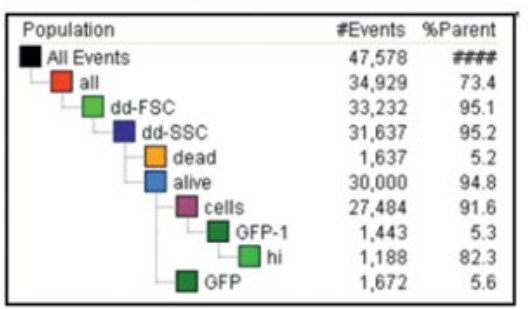
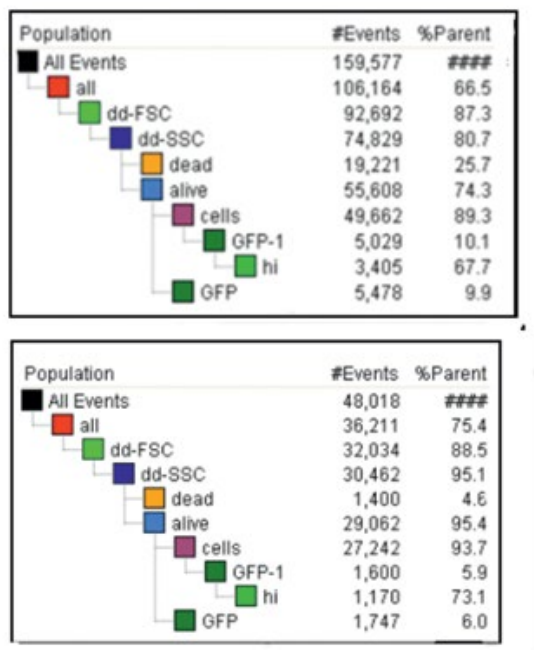

argon

\begin{tabular}{|lrr|}
\hline Population & \#Events & \%Parent \\
All Events & 87,185 & $7 \%$ F \\
$\square$ all & 70,287 & 80.6 \\
$\square$ dd-FSC & 66,490 & 94.6 \\
$\square$ dd-SSC & 63,313 & 95.2 \\
$\square$ dead & 3,178 & 5.0 \\
$\square$ alive & 60,135 & 95.0 \\
$\square$ cells & 55,596 & 92.5 \\
$\square$ GFP-1 & 647 & 1.2 \\
$\square$ Gi & 514 & 79.4 \\
$\square$ GFP & 777 & 1.3 \\
\hline
\end{tabular}
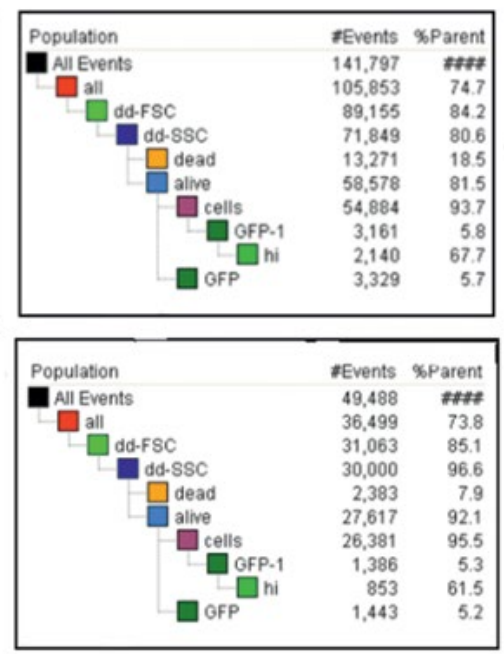

B

nitrogen
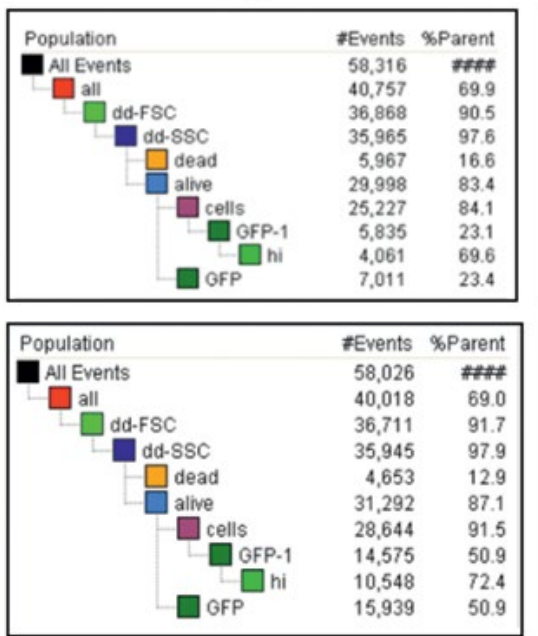

argon

\begin{tabular}{|c|c|c|}
\hline Population & \#Events & \%Parent \\
\hline All Events & 54,834 & $\# \#$ \\
\hline & 39,517 & 72.1 \\
\hline & 36,909 & 93.4 \\
\hline & 36,264 & 98.3 \\
\hline & 5,814 & 16.0 \\
\hline & 30,450 & 84.0 \\
\hline & 26,221 & 86.1 \\
\hline & 4,404 & 16.8 \\
\hline & 3,102 & 70.4 \\
\hline & 5,166 & 17.0 \\
\hline
\end{tabular}

\begin{tabular}{|c|c|c|}
\hline Population & FEvents & \%Parent \\
\hline All Events & 56,049 & $\#$ \\
\hline all & 42,592 & 76.0 \\
\hline c & 37,797 & 88.7 \\
\hline & 36,610 & 96.9 \\
\hline & 3,683 & 10.1 \\
\hline & 32,927 & 89.9 \\
\hline & 29,325 & 89.1 \\
\hline & 13,553 & 46.2 \\
\hline & 10,061 & 74.2 \\
\hline & 15,169 & 46.1 \\
\hline
\end{tabular}

Fig. 4. Transfection yield in different experiments. a) 3 experiments, conducted with PEI. b) 2 experiments, conducted with TurboFect. 
based mixture. On average, the number of fluorescent eGFP + cells in nitrogen-based mixture, was significantly, 2.58-fold higher, than in control groups, whereas only 1.37 -fold in argon-based mixture (Fig. 5).

Interestingly, in our previous works, the positive impact on proliferative potential and MSC morphology in nitrogen-based and argon-based mixtures was nearly at the same level, only slightly stronger in nitrogen-based mixture [21, 28]. However, in the groups, cultivated in argon-based mixtures, the enhancement of transfection effectiveness was much less pronounced, despite the same concentration of oxygen in mixture.

The "Liveldead" assay performed with BD FACSAria showed that the percentage differences between control and experimental groups were not significant (on average, $89.6 \pm 5.29 \%$

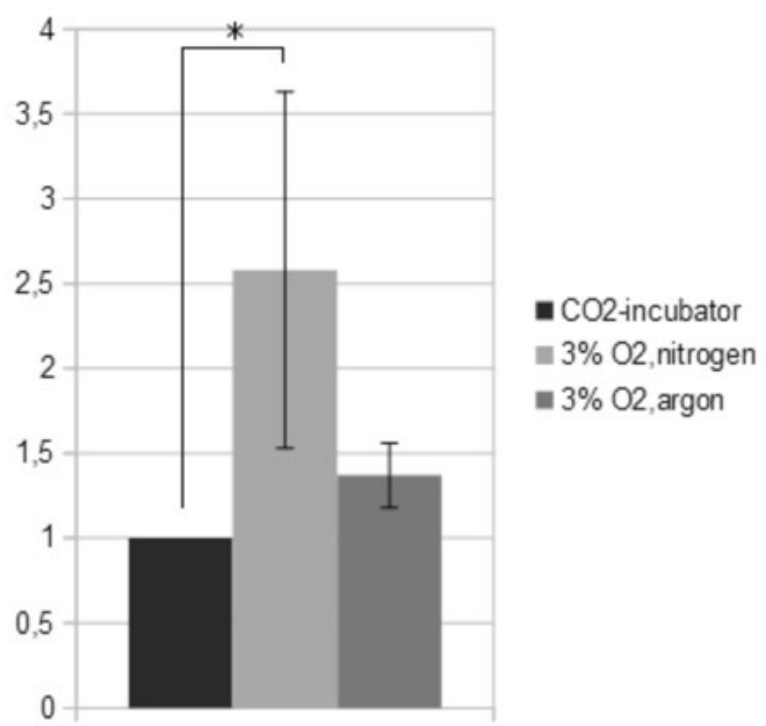

Fig. 5. Experimental/control ratio between the percentage of eGFP + cells. Results are represented as mean \pm $\mathrm{SEM}, \mathrm{n}=7 ; * \mathrm{P}<0.05$ in control group, $85.85 \pm 7.4 \%$ in nitrogenbased mixture, and $88.4 \pm 5 \%$ in argon-based mixture, data shown as mean \pm SD). However noteworthy, the number of live cells appeared to be slightly lower in both gas mixtures.

We realize, that in this pilot study, the obtained data are not sufficient for full statistical treatment. The individual features of the donor (like, potentially, the peculiarities of protein expression) may be the cause of marked difference between the cultures. Interestingly, other researchers have also described the difference in transfection efficiency between the cultures, obtained from different donors. For example, Madeira et al. described, that in the set of experiments, the percentage of GFP+ cells was 4-fold higher for one of the donors, though the number of plasmid copy per cell was approximately similar [30].

Despite the current interest in developing safe methods of genetic modification of MSCs, we should note that rather small share of all transfection research involves non-viral transfection prodecures [31]. Besides, the difference in experiment conduction hampers the comparison and analysis of the data, known from literature. Moreover, it is important to note that MSC properties may vary in the populations of different tissue origins and different donors $[1,3]$. As far as we know, at present, our work is the only one, which focuses on using the cultivation under physiologic oxygen concentrations as a transfection optimization method, so we are not able to compare our results with the data, obtained by other investigators. However, the enhancement of the efficiency of transfection shown in this work may be explained by other findings concerning the 
impact of mild hypoxia conditions on MSC in general.

At present, many researchers described, that the conditions of mild hypoxia can increase the number of proliferating cells in MSC culture, and in WJ-MSC cultures as well $[32,33]$. Recently, Zhang et al. [18] showed, that MSC from bone marrow, cultivated under lower oxygen tensions ( $1 \%$ and $5 \%)$, had higher proliferation rates and greater percentage of cells in $\mathrm{S}+\mathrm{G} 2 / \mathrm{M}$-phase, comparing to normoxia. Possibly, enhancement of proliferation in MSC cultures under low oxygen tensions is often accompanied by the shift in cell cycle propagation, comparing to standard cultivation conditions.

There are several works which show that the effectiveness of transfection, especially for the methods using cationic carriers, depends on the cell cycle phase [34,35] and the proliferative characteristics of cultures. For example, some works demonstrated that the cultivation conditions, inhibiting the division of human MSC, can reduce transfection efficiency [36].

Usually, in research works on mammalian cell transfection, large number of initially plated cells is used to facilitate further analysis (for example, flow cytometry) [37]. In this connection, it is important to mention the data of Boura et al. [38], who described the impact of plating density of MSC on transfection efficiency, and showed the possibility to enhance the efficiency of MSC transfection by performing the procedure on the actively proliferating MSC cultures. The authors [38] used the initial plating density (1000 and 3000) that allowed the culture to proliferate. The transfection procedure was conducted in 72 hours to confirm the division of cell in the cultures. This ap- proach provided an increase in the effectiveness of lipofection by two - to three-fold, comparing to their previous works.

We hypothesize, that in our work the enhancement of transfection efficiency in the cultures, maintained under physiological oxygen tension, can possibly have similar underlying mechanism. In our previous works, we showed that MSC cultures had higher proliferation rates under $3 \%$ oxygen, comparing to the standard conditions of $\mathrm{CO}_{2}$-incubator [21]. Though, it is important to note that in the present work we used a higher plating density (nearly 9400 per $\mathrm{cm}^{2}$ ) than in the experiment with MSC multiplication (3000 cells per $\mathrm{cm}^{2}$ ). However, the monitoring of the cultures morphology showed the presence of dividing cells, which indicates that during the transfection procedures, at least a part of the culture was in the state of active proliferation (Fig. 3).

The enhancement of transfection efficiency was more prominent in the nitrogen-based gas mixture. This finding is in-line with our results on the WJ-MSC proliferation. Also noteworthy, the statistical evaluation did not show significant difference between the results from argon-based gas mixture and control group, though in 5 of 7 experiments the number of eGFP+cells was larger. In the present work, the period of WJ-MSC cultivation before transfection was much shorter, than the routine maintenance at one passage during the multiplication in vitro. Interestingly, in our previous works, the beneficial effects of argon-based gas mixtures manifested themselves only in long-term cultivation [22]. This fact is in accordance with the findings in the present work, but needs future investigation. 
The shift in the cell cycle propagation can probably be a possible reason for a higher transfection efficiency under lower oxygen tensions. In this connection, we hypothesize, that the experiments, conducted on the synchronized MSC cultures would be useful in the further studies on this phenomenon. But still, the use of physiological oxygen concentrations seems to be perspective approach to increase the effectiveness of transfection.

\section{Conclusions}

The developed method of using the cultivation under physiological oxygen tensions as the method of transfection optimization for human WJ-MSC allowed the increasing of the percentage of transfected cells. The impact of nitrogen-based and argon-based mixtures, containing oxygen in the same concentrations, differed: the effect of argon-based mixture was significantly less pronounced.

\section{Acknowledgment}

We would like to thank Ruban T.A., Morgunov P.V., Soroka M.P, and Kyryk V.M. for their valuable support of this project.

\section{REFERENCES}

1. Taghizadeh RR, Cetrulo KJ, Cetrulo CL. Wharton's Jelly stem cells: future clinical applications. Placenta. 2011; 32(Suppl 4):S311-5.

2. Hass R, Kasper C, Böhm S, Jacobs R. Different populations and sources of human mesenchymal stem cells (MSC): A comparison of adult and neonatal tissue-derived MSC. Cell Commun Signal. 2011; 9:12.

3. Lund TC, Kobs A, Blazar BR, Tolar J. Mesenchymal stromal cells from donors varying widely in age are of equal cellular fitness after in vitro expansion under hypoxic conditions. Cytotherapy. 2010; 12(8): 971-81.

4. Neri S. Genetic stability of mesenchymal stromal cells for regenerative medicine applications: a fundamental biosafety aspect. Int J Mol Sci. 2019; 20(10):2406.

5. Estrada JC, Torres Y, Benguría A, Dopazo A, Roche E, Carrera-Quintanar L, Pérez RA, Enríquez JA, Torres $R$, Ramírez JC, Samper E, Bernad $A$. Human mesenchymal stem cell-replicative senescence and oxidative stress are closely linked to aneuploidy. Cell Death Dis. 2013; 4(6):e691.

6. Jiang T, Xu G, Wang $Q$, Yang L, Zheng L, Zhao J, Zhang $X$. In vitro expansion impaired the stemness of early passage mesenchymal stem cells for treatment of cartilage defects. Cell Death Dis. 2017; 8(6):e2851.

7. He Y, Zhou S, Liu H, Shen B, Zhao H, Peng K, Wu X. Indoleamine 2, 3-dioxgenase transfected mesenchymal stem cells induce kidney allograft tolerance by increasing the production and function of regulatory T cells. Transplantation. 2015; 99(9):1829-38.

8. Huang B, Qian J, Ma J, Huang Z, Shen Y, Chen X, Sun $A$, Ge J, Chen $H$. Myocardial transfection of hypoxia-inducible factor- $1 \alpha$ and co-transplantation of mesenchymal stem cells enhance cardiac repair in rats with experimental myocardial infarction. Stem Cell Res Ther. 2014; 5(1): 22.

9. Delyagina E, Schade A, Scharfenberg D, Skorska A, Lux C, Li W, Steinhoff G. Improved transfection in human mesenchymal stem cells: effective intracellular release of pDNA by magnetic polyplexes. Nanomedicine. 2014; 9(7):999.

10. Papayannakos $C$, Daniel R. Understanding lentiviral vector chromatin targeting: working to reduce insertional mutagenic potential for gene therapy. Gene Ther. 2013; 20(6):581-8.

11. Schaffert D, Wagner $E$. Gene therapy progress and prospects: Synthetic polymer-based systems. Gene Ther. 2008; 15(16):1131-8.

12. Wang $W, X u X, L i Z$, Lendlein A, Ma N. Genetic engineering of mesenchymal stem cells by non-viral gene delivery. Clin Hemorheol Microcirc. 2014; 58(1):19-48. 
13. Mas-Bargues C, Sanz-Ros J, Román-Domínguez A, Inglés M, Gimeno-Mallench L, El Alami M, ViñaAlmunia J, Gambini J, Viña J, Borrás C. Relevance of oxygen concentration in stem cell culture for regenerative medicine. Int $J$ Mol Sci. 2019; 20(5):1195.

14. Estrada JC, Albo C, Benguría A, Dopazo A, LópezRomero P, Carrera-Quintanar L, Roche E, Clemente EP, Enríquez JA, Bernad A, Samper E. Culture of human mesenchymal stem cells at low oxygen tension improves growth and genetic stability by activating glycolysis. Cell Death Differ. 2012; 19(5):743-55.

15. Wang Z, Fang B, Tan Z, Zhang D, Ma H. Hypoxic preconditioning increases the protective effect of bone marrow mesenchymal stem cells on spinal cord ischemia/reperfusion injury. Mol Med Rep. 2016; 13(3):1953-60.

16. Liu H, Liu S, Li Y, Wang X, Xue W, Ge G, Luo X. The role of SDF-1-CXCR4/CXCR7 axis in the therapeutic effects of hypoxia-preconditioned mesenchymal stem cells for renal ischemia/reperfusion injury. PLoS One. 2012; 7(4):e34608.

17. Chen L, Xu Y, Zhao J, Zhang Z, Yang R, Xie J, Liu X, Qi $S$. Conditioned medium from hypoxic bone marrow-derived mesenchymal stem cells enhances wound healing in mice. PLoS ONE. 2014; 9(4): e96161.

18. Zhang J, Xiong L, Tang W, Tang L, Wang B. Hypoxic culture enhances the expansion of rat bone marrow-derived mesenchymal stem cells via the regulatory pathways of cell division and apoptosis. In Vitro Cell Dev Biol Animal. 2018; 54(9):666-76.

19. $H u$ C, $L i L$. Preconditioning influences mesenchymal stem cell properties in vitro and in vivo. $J$ Cell Mol Med. 2018; 22(3):1428-42.

20. Zhang L, Yang J, Tian YM, Guo H, Zhang Y. Beneficial Effects of Hypoxic Preconditioning on Human Umbilical Cord Mesenchymal Stem Cells. Chin J Physiol. 2015;58(5):343-53.

21. Shuvalova NS, Kordium VA. Comparison of proliferative activity of Wharton jelly mesenchymal stem cells in cultures under various gas conditions. Biopolym Cell. 2015; 31(3): 233-9.
22. Shuvalova NS, Kordium VA. Proliferation of Wharton jelly mesenchymal stem cells, derived by preserving the cells with reduced attachment rate, under various gas conditions. Biopolym Cell. 2015; 31(6):447-54.

23. Lykhmus O, Koval L, Voytenko L, Uspenska K, Komisarenko S, Deryabina O, Shuvalova N, Kordium V, Usty-menko A, Kyryk V, Skok M. Intravenously injected mesenchymal stem cells penetrate the brain and treat inflammation-induced brain damage and memory impairment in mice. Front Pharmacol. 2019; 10: 355.

24. Lykhmus O, Kalashnyk O, Koval L, Voytenko L, Uspenska K, Komisarenko S, Deryabina O, Shuvalova N, Kordium V, Ustymenko A, Kyryk V, Skok $M$. Mesenchymal Stem Cells or Interleukin-6 Improve Episodic Memory of Mice Lacking $\alpha 7$ Nicotinic Acetylcholine Receptors. Neuroscience. 2019; 413: 31-44.

25. Maslova OO, Shpilova SP, Shuvalova NS, Derybia $O G$, Kordium VA. Spontaneous formation of spheroids in human umbilical cord matrix derived cells culture. Biol Stud. 2012: 6(2); 79-86.

26. Shuvalova NS, Kordium VA. Morphological characteristics of mesenchymal stem cells from Wharton jelly, cultivated under physiological oxygen tensions, in various gas mixtures. Biopolym Cell. 2016; 32(4):262-70.

27. Freshney RI. Animal cell culture: a practical approach. Oxford: "IRL Press Limited", 1986. 348 p.

28. Kordyum VA, Toporova EK, Okunev OV, Pokholenko YA, Suchorada EM, Ruban TA, Andrienko VI, Irodov DM. Novel cell line with multiple markers, derivative of CHO-K1. Biopolym Cell. 2003; 19(3):252-6.

29. Toporova O, Pokholenko I, Shuvalova N, Kyryk V, Deriabina $O$, Morgunov P, Irodov D, Kordium $V$. Genetic engineering of mesenchymal stem cells from umbilical cord Wharton's jelly. World Conference on Regenerative Medicine at: Leipzig, Germany, October 2015. Regenerative Medicine 2015; 10 (07):220.

30. Madeira C, Mendes RD, Ribeiro SC, Boura JS, Aires-Barros MR, da Silva CL, Cabral JM. Nonviral gene delivery to mesenchymal stem cells using 
cationic liposomes for gene and cell therapy. J Biomed Biotechnol. 2010; 2010:735349.

31. Jo J, Tabata Y. Non-viral gene transfection technologies for genetic engineering of stem cells. Eur $J$ Pharm Biopharm. 2008; 68(1): 90-104.

32. Nekanti U, Dastidar $S$, Venugopal P, Totey $S, T a M$. Increased proliferation and analysis of differential gene expression in human Wharton's jelly-derived mesenchymal stromal cells under hypoxia. Int J Biol Sci. 2010; 6(5):499-512.

33. Lavrentieva A, Majore I, Kasper C, Hass R. Effects of hypoxic culture conditions on umbilical cordderived hu-man mesenchymal stem cells. Cell Commun Signal. 2010; 8:18.

34. Brunner S, Fürtbauer E, Sauer T, Kursa M, Wagner $E$. Overcoming the nuclear barrier: cell cycle independent nonviral gene transfer with linear polyethylenimine or electroporation. Mol Ther. 2002; 5(1):80-6.

35. Männistö $M$, Rönkkö S, Mättö M, Honkakoski P, Hyttinen M, Pelkonen J, Urtti A. The role of cell cycle on polyp-lex-mediated gene transfer into a retinal pigment epithelial cell line. J Gene Med. 2005; 7(4):466-76.

36. King WJ, Kouris NA, Choi S, Ogle BM, Murphy WL. Environmental parameters influence non-viral transfection of human mesenchymal stem cells for tissue engineering applications. Cell Tissue Res. 2012; 347:689-99.

37. Gheisari Y, Soleimani M, Azadmanesh K, Zeinali $S$. Multipotent mesenchymal stromal cells: optimization and comparison of five cationic polymer-based gene delivery methods. Cytotherapy. 2008;10(8): 815-23.

38. Boura JS, Santos FD, Gimble JM, Cardoso CM, Madeira C, Cabral JM, Silva CL. Direct head-tohead compari-son of cationic liposome-mediated gene delivery to mesenchymal stem/stromal cells of different human sources: a comprehensive study. Hum Gene Ther Methods. 2013; 24(1): $38-48$.

\section{Трансфекція мезенхімальних стовбурових клітин при фізіологічних концентраціях кисню}

\author{
Н. С. Шувалова, О. К. Топорова, В. А. Кордюм
}

Мета. Численні роботи показали позитивний вплив фізіологічних концентрацій кисню на культури мезенхімальних стовбурових клітин (МСК). Метою даної роботи було дослідження впливу фізіологічних концентрацій кисню на ефективність невірусної трансфекції МСК Вартонового студню (МСК-ВС). Методи. МСКВС на другому пассажі було культивовано 48 годин в різних газових сумішах: на основі азоту (кисень $-3 \%$, $\mathrm{CO}_{2}-5 \%$, азот - $92 \%$ ), і на основі аргону (кисень $3 \%, \mathrm{CO}_{2}-5 \%$, аргон - $92 \%$ ). Контрольну групу тримали в стандарнтих умовах $\mathrm{CO}_{2}-$ інкубатора (атмосферна концентрація кисню, $\mathrm{CO}_{2}-5 \%$ ). Після 48 годин культивування клітини було трансфіковано нанорозмірними поліплексами $\mathrm{pEGFP-C1/PEI} \mathrm{та} \mathrm{pEGFP-C1/}$ TurboFect, що містили 3 мкг плазмідної ДНК. Культури перебували в контакті з комплексами приблизно 1 годину, в умовах $\mathrm{CO}_{2}-$ інкубатора. Після чого дослідні культури було культивовано в зазначених вище газових сумішах (при 3 \% кисню), а контрольну - та в умовах $\mathrm{CO}_{2}$ - інкубатора. Ефктивність трансфекції оцінювали за допомогою проточної цитофлюориметрії, як число флюоресцентних клітин, що експресують еGFP. Результати. У групах, які було культивовано в газових сумішах, що містили 3 \% кисню, до та після процедури трансфекції, кількість клітин, що синтезують eGFP, була більшою в середньому у 2,58 в суміші на основі азоту, та 1,37 рази в суміші на основі аргону. Висновки. Культивування МСК-ВС за фізіологічних концентрацій кисню можна використовувати як метод підвищення ефективності невірусної трансфекції.

Кл ю ч о в і с л о в а: мезенхімальні стовбурові клітини, Вартонів студень, невірусна трансфекція, трансфекція, гіпоксія, аргон

\section{Трансфекция мезенхимальных стволовых клеток при физиологических концентрациях кислорода}

Н. С. Шувалова, Е. К. Топорова, В. А. Кордюм

Цель. Многие исследования показали положительное влияние физиологических концентраций кислорода на 
культуры мезенхимальных стволовых клетин (МСК). Целью данной работы было исследование влияния физиологических концентраций кислорода на эффективность невирусной трансфекции МСК Вартонова студня (МСК-ВС). Методы. МСК-ВС, на втором пассаже, были культивированы 48 часов в различных газовых смесях: на основе азота (кислород - $3 \%$, $\mathrm{CO}_{2}-5 \%$, азот $-92 \%$ ) и на основе аргона (кислород $3 \%, \mathrm{CO}_{2}-5 \%$, аргон - $\left.92 \%\right)$. Контрольную группу содержали в стандартных условиях $\mathrm{CO}_{2}-$ инкубатора (атмосферная концентрация кислорода, $\mathrm{CO}_{2}-5 \%$ ). После 48 часов культивирования клетки были трансфицированы наноразмерными полиплексами pEGFP-C1/PEI и pEGFP-C1/TurboFect, содержащими 3 мкг плазмидной ДНК. Культуры находились в контакте с комплексами примерно 1 час, в условиях $\mathrm{CO}_{2}-$ инкубатора, после чего экспериментальные группы МСК-ВС культивировали в указанных выше газовых смесях, содержащих 3 \% кислорода, а контрольную в условиях $\mathrm{CO}_{2}-$ инкубатора. Эфективность трансфекции оценивали с помощью проточной цитофлюориметрии, как число флюоресцентных клеток, экспрессирующих eGFP. Результаты. В группах, культивированых в газовых смесях, содержащих 3 \% кислорода, до и после процедуры трансфекции, количество клеток, синтезирующих eGFP, была больше в среднем в 2,58 в смеси на основе азота, и 1,37 раза в смеси на основе аргона. Выводы. Культивирование МСК-ВС при физиологических концентрациях кислорода можно использовать как метод повышения эффективности невирусной трансфекции.

Кл юч е в ы е сл о в а: мезенхимальные стволовые клетки, Вартонов студень, невирусная трансфекция, трансфекция, гипоксия, аргон.

Received 05.05.2020 